\title{
Cooperative Empowerment Strategy in the Keerom Regency, Papua Province
}

\author{
Dolf Eduard Mitteboga \\ Institute of State Government (IPDN) Jayapura, Papua, Indonesia
}

\begin{abstract}
During this time, many cooperative development programs have been implemented in the Keerom Regency, but its impact is only visible to the growing number of cooperatives, and have not been able to touch the main targets, namely poverty reduction and employment growth. This is an indication of unsuccessful implementation of the empowerment programs. Starting from this reality, it is necessary to understand the implementation of cooperative empowerment programs in the Keerom Regency; identify the constraints faced; and to formulate strategies for the empowerment of cooperatives.
\end{abstract}

Keywords: cooperative, empowerment, institutional aspects, environmental aspects, phenomenology.

\section{Introduction}

The main target of cooperative empowerment is to facilitate the poor who are members of the cooperative as comprised in the cooperative empowerment for the purpose of enabling the cooperative, utilizing the existing resources of the cooperative so the benefits can be in harmony with the actual purpose of the establishment of the cooperative, which is the welfare of its members. Similarly, the empowerment of cooperative programs in Keerom Regency, the main target was also expected to eventually facilitate the members of the cooperative. As set forth in RPMJD - Rencana Pembangunan Jangka Menengah Dareah (medium-term development plan of an area), of Keerom Regency, that one area of the development policy agenda is to create prosperity and independence of the community, one of which can be achieved by establishing the existence of the cooperative. That is to say, the cooperatives are encouraged to act more independently as a mediator of community empowerment (which is the members).

In Keerom Regency case, there are many cooperatives that are not able to fulfil their role as the mediator of community empowerment. Numerous measure of success of the program cannot be achieved, such as: institutional performance measures, and a measure of the influence the program has towards its objects. This is what encourages this article to delve more deeply about the current implementation of cooperative empowerment programs in Keerom Regency; to identify the constraints encountered; and to realise the implications for the authority of cooperatives, cooperative itself and its members.

\section{The Type Of Empowerment Program And The Sources Of Funds}

A number of cooperatives empowerment programs in Keerom Regency had been implemented since the separation of Keerom from Jayapura Regency in order to bring forth prosperity and independence of the local communities. Up to now, the sources of funds of the cooperatives empowerment programs are not only derived from the Keerom Regency APBD - Anggaran Pendapatan Daerah (Revenue and Expenditure budget of a region), but some are also derived from the $A P B D$ of the regional Government of Papua Province, as well as from the APBN - Anggaran Pendapatan dan Belanja Negara (revenue and expenditure budget of the country), of the Central Government (Ministry of Cooperatives). Cooperative empowerment programs that are funded by the Government of Papua are using Special Autonomy Fund (dana Otonomi Khusus), while cooperative empowerment program funded by the Central GOvernment are using P3KUM funds - Program Pembiayaan Produktif Koperasi dan Usaha Mikro (financing of productive cooperative programs and microenterprises), from the Ministry of Cooperatives and Small and Medium Enterprises.

Cooperative empowerment programs in Keerom Regency that comes from the Central Government and are funded by the $A P B N$ (revenue and expenditure budget of the country), through schemes such as P3KUM (financing of productive cooperative programs and microenterprises), but some are also taken from the PKPSBBM - Program Kompensasi Pengurangan Subsidi Bahan Bakar Minyak (subsidy reduction compensation program - fuel oil). Such programs fall under the category of revolving funds program and have been implemented since 2003. There are two cooperatives in Keerom Regency that are privileged to get portions of P3KUM revolving funds, KSP - Koperasi Simpan Pinjam (credit unions) Keerom Mandiri and KSP Ranu Wisau. Likewise, there are also two cooperative empowerment program that are commended to distribute PKPS$B B M$ funds, Savings and Loans unit (USP - Unit Simpan Pinjam) Village Unit Cooperative (KUD - Koperasi Unit Desa) of Arso Indah, as well as KSP Cooperative Two, which occurred to be the subject of this study. The 
programs from both $P 3 K U M$ and $P K P S-B B M$, each cooperative would receive Rp 100 Million with a tenor of 10 years.

There are other cooperative empowerment programs for cooperatives in Keerom Regency by the Central Government, however they are within different schemes (not part of either P3KUM or PKPS-BBM), which is Perkassa - Program perempuan keluarga sehat dan sejahtera (Women's program for healthy and prosperous family). Perkassa is also a product from the Ministry of Cooperatives and Small and Medium Enterprises. Perkassa is a program that supports the capital of credit unions or cooperatives that are funded by the Islamic financial services, whose members are mostly women. Additionally, through Perkassa, it is expected that institutional advocacy would occur, as well as character building among women entrepreneurs, especially those who are members of women cooperatives and groups of businesses run by women in micro and small scale. Similar to P3KUM as well as PKPS-BBM, Perkassa provides capital assistance in the form of loan assistance to cooperative to be distributed to the members with certain conditions applied and through a revolving fund mechanism. The cooperative in Keerom Regency that is privileged to channel the Perkassa revolving funds is Cooperative Four. The amount of funds received by Cooperative Four from Perkassa scheme is $\mathrm{Rp} 600$ million, and the allocation of the funds occurred in 2006.

In addition to cooperative empowerment programs that are funded by the Central Government, there are also a number of programs coming from the Provincial Government of Papua and the Keerom Regency Regime itself. The funding of the programs that comes from the Provincial Government of Papua is sourced by the Special Autonomy Fund (Dana Otonomi Khusus). Whereas programs that are from the Keerom Regency Regime are funded by DAU - Dana Alokasi Umum (General Allocated Fund).

Empowerment program, whose fund is derived from $D A U$, is referred to as cooperative and small and medium enterprises empowerment program $(P P K U)$, whereas that of special autonomy funds (dana otonomi khusus), the program is referred to as the program that creates conducive small business climate (PPIUKK). In 2006, through $P P K U$ a total fund of Rp 900 million was disbursed to the 45 cooperatives in Keerom Regency and each of them gets Rp 20 million. In the same year, through PPIUK, Rp 100 million was also channeled for 10 cooperatives in Keerom Regency, where each cooperative would acquire Rp 10 million. In 2007, the amount of funds channeled through both $P P K U$ and PPIUKK in Keerom Regency was even greater. PPKU distributed Rp 1 billion and PPIUKK distributed a total of Rp 525 million, Through $P P K U, 7$ cooperatives obtained a quota amounting to $\mathrm{Rp} 100$ million each, and 6 cooperatives obtained Rp 50 million each. While through PPIUKK, 40 cooperatives received a quota amounting to RP 10 million each. The total funds that were spent by the Provincial Government of Papua, in order to empower cooperatives in Keerom Regency in 2006 was Rp 100 million, and in 2007 it elevated up to RP 525 million. Whereas the total funds that were disbursed by the local Keerom Regency Regime in 2006 was Rp 900 million, and increased up to Rp 1 billion in 2007.

\section{Cooperative Empowerment In Reality In The Keerom Regency}

In general, Sumodiningrat (1999) stated that the success of an empowerment program should be as a whole, which is through institutional work performance measurement and the measurement of the effect the program has towards its objects. Measurements must also take into account the aim or the goal of the program itself. In the case of cooperative empowerment in Keerom Regency, the beauty of the cooperative empowerment model while it was still at the concept level was not duly delivered on the level of immplementation. Institutional work performance programs measurement have many purposes that were not achieved, let alone the measurements of the effect of the program towards its objects.

Indication of ussuccessfulness (if it was not intended to be labelled as failure) of a number of cooperative empowerment programs in Keerom Regency is the amount of objectives of the programs that were not realized. One of the goals or objectives of cooperative empowerment programs, such as: $P 3 K U M$, PKPS$B B M$, Perkassa, and many others, is to disburse revolving funds to one $K S P / U S P$ cooperative that meets the requirements of the program, in which one of the conditions is for a $K S P / U S P$ cooperative that recieves the revolving fund must be an active $K S P / U S P$ cooperative as measured by the fact that the cooperative is incorporated for at least 1 year, and has implemented the RAT-Rapat Anggota Tahunan (annual members' meeting) in the last fiscal year.

The Reality on the field would say otherwise. The discoveries in the field indicated that there are numerous cooperatives in the Keerom Regency that are obviously do not meet the current conditions, one of which was inactive, but can still partake in the cooperative empowerment program. One of these cooperatives is Cooperative Two. In 2003, Cooperative Two received funding assistance from coopeartive empowerment program through $P K P S-B B M$ of Rp 100 million. When receiving the revolving fund, Cooperative Two could not be categorised as an active cooperative since it did not meet the requirement to meet the legal status for at least 1 year, and has implemented the $R A T$ in the last fiscal year. Cooperative Two legal entity was officially granted on 27 March 2003, and the assistance of revolving funds from PKPS-BBM was received by the end of 2003, around November. Meaning that at the time Cooperative Two received the revolving funds assistance from $P K P S-B B M$, 
the legal entity of Cooperative Two was barely a year old, or rather was 8 months old. Additionally, since the revolving funds assistance from $P K P S-B B M$ was received in November, then it can be concluded that Cooperative Two had not implemented $R A T$ at the time of receiving the revolving funds assitance from PKPS$B B M$, as referred to Article 26 of the Law of the Republic of Indonesia Number 25 of 1992 on Cooperatives, $R A T$ of the year 2003 can only be implemented after the end of fiscal year of 2003.

Cooperative Two case was actually the tip of an iceberg, whose bulk could not be seen as it was submerged under the sea. Meaning, there are many cooperative that are not active in Keerom Regency, which are partaking in the cooperative empowerment programs (see table 1).

Table 1. Number of active and inactive cooperatives, who are the beneficiaries of the revolving funds assistance for the cooperative empowerment in Keerom Regency.

\begin{tabular}{|c|c|c|c|c|c|c|c|c|}
\hline \multirow{3}{*}{ Tahun } & \multirow{3}{*}{ Nama Program } & \multirow[t]{3}{*}{ Sumber } & \multirow{3}{*}{$\begin{array}{l}\text { Nilai } \\
\text { Rp }\end{array}$} & \multirow{2}{*}{\multicolumn{2}{|c|}{$\begin{array}{c}\text { Koperasi } \\
\text { Penerima }\end{array}$}} & \multicolumn{3}{|c|}{ Kop. Aktif/Tidak Aktif } \\
\hline & & & & & & \multirow[t]{2}{*}{ Aktif } & \multirow[t]{2}{*}{ TA } & \multirow{2}{*}{$\begin{array}{l}\text { TA tapi } \\
\text { menerima } \\
\text { bantuan }\end{array}$} \\
\hline & & & & Unit & Total & & & \\
\hline 2006 & $\begin{array}{l}\text { - Pemberdayaan Koperasi dan UKM } \\
\text { - Program Penciptaan Iklim Usaha } \\
\text { Kecil yang Kondusif }\end{array}$ & $\begin{array}{l}\text { DAU } \\
\text { Otsus }\end{array}$ & $\begin{array}{l}900.000 .000 \\
100.000 .000\end{array}$ & $\begin{array}{l}45 \\
10\end{array}$ & 55 & 23 & 55 & 32 \\
\hline 2007 & $\begin{array}{l}\text { - Pemberdayaan Koperasi dan UKM } \\
\text { - Program Penciptaan Iklim Usaha } \\
\text { Kecil yang Kondusif }\end{array}$ & $\begin{array}{l}\text { DAU } \\
\text { Otsus }\end{array}$ & $\begin{array}{r}1.000 .000 .000 \\
525.000 .000\end{array}$ & $\begin{array}{l}13 \\
40\end{array}$ & 53 & 24 & 56 & 29 \\
\hline
\end{tabular}

Source: Department of Cooperatives, Small and Medium enterprises, Trades and Industries of Keerom Regency (has been processed).

In 2006, from the total of 55 cooperatives revolving funds recipients, there were 32 cooperatives (58.18\%) that were inactive or were ineligible to receive the assistance provided. An error within the selection that are hard to believe but happened to be the reality. That number declined slighly in 2007 , from the total of 53 cooperatives revolving fund recipients, there were 29 cooperatives $(54.72 \%)$ that were inactive but would still partake in the cooperatives empowerment programs. Although there was a slight decline of the selection error from 2006 to 2007, but the reality was that the potential losses in absolute terms had swelled up. Assuming that the revolving funds assistance received by the active cooperatives could be managed appropriately, then the potential losses due to the adverse selection in 2006 was approximately Rp 582 million, which was calculated from the percentage of the inactve cooperatives that recieved assistance $(58.18 \%)$ multiplied by the total amount of revolving funds in 2006, which is Rp 1 billion. In 2007, the potential losses due to the adverse selection would elevate to approximately $\mathrm{Rp} 834$ million ( $54.72 \%$ x Rp 1.525 billion).

Another requirement for accessing cooperative empowerment programs in Keerom Regency os that a cooperative candidate must have at least 25 members, which are composed of mostly women micro enterpreneurs. Can this requirement really be a filter in the selection of the cooperatives who are entitled to can gain access to the empowerment program? The answer can be seen in numerous samples who had recceived the revolving funds assistance, as presented in Table 2.

In Table 2, it appears that from 8 cooperatives samples that were studied, there was only 1 quialified cooperative whose members are mostly women micro entrepreneurs, which is Cooperative Two. According to the data received from the Department of Cooperatives, Small and Medium Enterprises, Trades and Industries of the Keerom Regency, Cooperative Two has a majority of women members. With a total membership of 71 people, there are 41 women members and the remaining 30 were men. Where as 7 other cooperatives that were also sampled, the members are mainly comprised by the men. It also suggests that the condition of the composition of cooperatives members should be dominated by women, were ignored during the selection process for the eligibility of access to the program.

Table 2. The number of members of the cooperative based on their gender; from numerous Cooperatives that received the revolving funds assistance for the cooperative empowerment in Keerom Regency.

\begin{tabular}{|c|c|c|c|c|c|c|c|}
\hline \multirow[t]{2}{*}{ No. } & \multirow[t]{2}{*}{ Nama Koperasi } & \multirow{2}{*}{$\begin{array}{c}\text { Tahun } \\
\text { Realisasi }\end{array}$} & \multirow{2}{*}{$\begin{array}{l}\text { Jml Bantuan } \\
\text { Diterima }\end{array}$} & \multicolumn{4}{|c|}{ Jumlah Anggota } \\
\hline & & & & $\mathbf{L}$ & $\mathbf{P}$ & Total & Keterangan \\
\hline 1 & Koperasi Satu & 2007 & 20.000 .000 & 30 & 10 & 40 & \\
\hline 2 & Koperasi Dua & 2003 & 100.000 .000 & 30 & 41 & 71 & \\
\hline \multirow[t]{3}{*}{3} & Koperasi Tiga & 2006 & 15.000 .000 & 20 & 6 & 26 & \\
\hline & & 2007 & 5.000 .000 & & & & \\
\hline & & 2009 & 3.000 .000 & & & & \\
\hline 4 & Koperasi Empat & 2006 & 600.000 .000 & 148 & 37 & 185 & \\
\hline 5 & Koperasi Lima & 2006 & 10.000 .000 & & & 40 & \\
\hline 6 & KUD Arso Indah & 2003 & 100.000 .000 & 214 & 71 & 285 & \\
\hline 7 & KSP Keerom Mandiri & 2007 & 100.000 .000 & & & & tdk ada data \\
\hline 8 & KSP Ranu Wisau & 2007 & 100.000 .000 & & & & tdk ada data \\
\hline
\end{tabular}

Source: Department of Cooperatives, Small and Medium enterprises, Trades and Industries of Keerom Regency (has been processed). 
Still associated with the same reirements, which is the cooperative candidate for the assistance must have a mínimum of 25 members who are mostly women micro enterpreneurs, the case involving Cooperative Four is very interesting to be eobserved. Although the data from the Department of Cooperatives of the Keerom Regency in Table 2 mentioned that the number of Cooperative Four members were as many as 185 people, but the reality showed otherwise. When selectes as one of the cooperatives that are eligible to participate in empowerment program, Cooperative FOur did not have any members, there were only its management team, the chairman and treasurer.

Another violation of the revolving funds assistance conditions that are found in Cooperative Four was the violation of the maximum amount of revolving funds assistance that can be distributed to cooperatives. The revolving funds assistance for Cooperative For was derived from Perkassa. One of the goals of the revolving funds of Perkassa is to strengthen the capital in the form of long-term loan, which is 10 years, with the average loan size of Rp 100 million. However the fact was that Cooperative Four received a revolving funds assitance from Perkassa of Rp 600 million (see table 1), or 6 times greater than its requirements. One of the board member of Cooperative Four acknowledged to the fact that the cooperative had recieved a funding assistance of RP 600 million. Even as the responsible party of the implementation of the program, the Deparment of Cooperatives of Keerom Regency did not deny to the fact that Cooperative Four had received an a funding assistance of Rp 600 million through the Perkassa program.

There is another thing that is still associated with the revolving funds assistance received by the Cooperative Four from Perkassa. One of the objectives or goals of Perkassa is to cannel through the revolving funds from $K S P / U S P$ cooperative to its members, namely micro enterprises that are run by women who are qualified for a loan. Meaning, the revolving funds assistance received from Perkassa must be disbursed by the receiving cooperative to its members in the form of loans. However, the actual fact was that the revolving funds assitance received from Perkassa of Rp 600 million, which was also recieved by Cooperative Four, was not disbursed to its members in the form of loans, instead it was used to finance the construction of the cooperative offices in the amount of Rp 500 million, and the remaining Rp 100 million was used to procure 9 type of the staples and to cover the cost of inauguration of the cooperative office building. Seemingly it had received the approval of the person in charge of the program, namely the Department of cooperative of Keerom Regency. All of this can be the proof that there has been an inappropriate distribution of the revolving funds assitance from Perkassa to Cooperative Four.

Table 3.Development of the distribution of revolving funds assistance for the cooperative empowerment in Keerom Regency

\begin{tabular}{|l|l|c|c|r|r|r|}
\hline No. & Nama Koperasi & $\begin{array}{c}\text { Tahun } \\
\text { Realisasi }\end{array}$ & $\begin{array}{c}\text { Jangka } \\
\text { Waktu }\end{array}$ & $\begin{array}{c}\text { Jml Bantuan } \\
\text { Diterima }\end{array}$ & $\begin{array}{c}\text { Angsrn Pokok } \\
\text { Telah Dibayar }\end{array}$ & $\begin{array}{c}\text { Sisa Pokok } \\
\text { Harus Dibayar }\end{array}$ \\
\hline 1 & Koperasi Satu & 2007 & - & 20.000 .000 & - & 20.000 .000 \\
2 & Koperasi Dua & 2003 & 10 tahun & 100.000 .000 & - & 100.000 .000 \\
3 & Koperasi Tiga & 2006 & - & 15.000 .000 & - & 15.000 .000 \\
& & 2007 & - & 5.000 .000 & - & 5.000 .000 \\
& & 2009 & - & 3.000 .000 & - & 3.000 .000 \\
4 & Koperasi Empat & 2006 & 10 tahun & 600.000 .000 & - & 600.000 .000 \\
5 & Koperasi Lima & 2006 & - & 10.000 .000 & - & 10.000 .000 \\
6 & KUD Arso Indah & 2003 & 10 tahun & 100.000 .000 & - & 100.000 .000 \\
7 & KSP Keerom Mandiri & 2007 & 10 tahun & 100.000 .000 & - & 100.000 .000 \\
8 & KSP Ranu Wisau & 2007 & 10 tahun & 100.000 .000 & - & 100.000 .000 \\
\hline
\end{tabular}

Source: Department of Cooperatives, Small and Medium enterprises, Trades and Industries of Keerom Regency (has been processed).

The numbers of cooperative empowerment program objectives that are not realised, and the existense of violations of the terms or conditions in its distribution, as previously described, os a testament to the failure of cooperative empowerment programs in Keerom Regency. Therefore, if the measure of success of a program is its ability to achieve is goals, then evidently the cooperative empowerment programs in Keerom Regency was not successful. What if the measure of success is the repayment rate of the revolving funds assistance? The aswer would still be the same, that the cooperative empowerment in Keerom Regency had not been successful. This can be seen from the remaining primary amount to be paid by each beneficiary cooperative. Remaining primary amount to be paid by 8 cooperatives that were sampled is still the same amount as it was originally received by each of the coopeartive (see Table 3). Meaning, there was not a single one of these cooperatives that have made payment for the primary funding assitance, or the repayment rate was equal to $0 \%$ (zero percent). 


\section{Behind The Unsuccessfulness Of Cooperative Empowerment In Keerom Regency}

There are a number of things found in the fields that are related to the probles or cause of the failure of cooperative empowerment in Keerom Regency. These factors were clustered into two groups: factors related to the institutional aspects, as well as the environmental aspects.

\subsection{Institutional Aspects}

a. Asymmetric Information

As described by Varian (1993), and imbalance of information or asymmetric information is a situation where one side of the market would not be able to know or observe the actions of another party. One of the sides would have a different amount of information (asymmetric) compared to the information owned by the other party. A party with more complete information would be able to refract the other party (Nicholson 1995). Whereas Mishkin (1997), described asymmetric information as a situation in which each party within a contractial relationship does not have the same information. This condition would get worse if there was also a moral hazard problem within, as stated by Mishkin (1997).

In this case, the cooperative that is directly dealing with the members would be in a better position to master the information in comparison to the cooperative authorities. Cooperative authority had actually tried reduce the asymmetric information problem by performing monitoring in the form of requiring the cooperatives to submit financial statements (annual reports) after the $R A T$ to the cooperative authority. However that was not enough, the cooperative had always been in the position of the parties with detailed information because it is directly dealing with the source of information (its members, the cooperative conditions, and many others). This position can easily make it refracts the other party (cooperative authority).

Table 4.A summary of the whole cooperatives in Keerom Regency

\begin{tabular}{|l|l|c|c|r|r|}
\hline \multirow{2}{*}{ No. } & \multirow{2}{*}{ Nama Koperasi } & \multicolumn{2}{|c|}{ Keaktifan Koperasi } & \multicolumn{2}{c|}{ Jumlah Anggota } \\
\cline { 3 - 6 } & & $\begin{array}{c}\text { Menurut } \\
\text { Dinkop }\end{array}$ & $\begin{array}{c}\text { Hasil } \\
\text { Survei }\end{array}$ & $\begin{array}{c}\text { Menurut } \\
\text { Dinkop }\end{array}$ & $\begin{array}{c}\text { Hasil } \\
\text { Survei }\end{array}$ \\
\hline 1 & Koperasi Satu & tidak aktif & tidak aktif & 40 & tidak ada \\
2 & Koperasi Dua & aktif & tidak aktif & 71 & 27 \\
3 & Koperasi Tiga & tidak aktif & tidak aktif & 26 & 22 \\
4 & Koperasi Empat & aktif & tidak aktif & 185 & tidak ada \\
5 & Koperasi Lima & tidak aktif & aktif & 40 & 40 \\
\hline
\end{tabular}

Source: Department of Cooperatives, Small and Medium enterprises, Trades and Industries of Keerom Regency (has been processed).

Evidences that there is asymmetric information between the cooperative authorty in Keerom Regency with the cooperatives within its region can be seen in Table 4. There is a gap between the data owned by the Department of Cooperatives of Keerom Regency with the actual fact resulted from the survey on the field. For example, in relation to the active status of a cooperative, in accordance to the cooperative authority of Keerom Regency, from 5 cooperatives studied there were only two that were active, namely Cooperative Two and Cooperative Four (see Table 4). However, the results of the direct survey to each cooperative showed that there was only 1 active cooperative, nameli Cooperative Five, whereas the other 4 were not active.

Asymmetric information is not only surfacing in information related to whether or not a cooperative is active, but also to the data on the number of cooperative members. From 5 cooperatives observed, there was only one cooperative that does not have a data gap between the data obtained by the Deparment of Cooperatives of Keerom Regency wih the survey data, Cooperative Five (see Table 4). The most severe data gaps occur to Cooperative One and Cooperative Four. According to the Department of Cooperatives of Keerom Regency, the amount of members of Cooperative One is 40 people. A direct survey in the field showed that Cooperative One apparently did not have any members. Indeed, at the start of its establishment, around 2004, Cooperative one had a membership of 32 people, but before receiving the revolving funds assistance in 2006, all of its members had resigned, and up to today Cooperative One does not have a single member.

Severe data gaps on the membership of the cooperatives also occured to Coopeative Four. Department of Cooperatives of Keerom Regency suggested that the number of members of Cooperative Four was as many as 185 people (see table 4). However, this data was contrary with the data coming from the direct survey of the field, apparently Cooperative Four was similiar to Cooperative One, in the sense that it has not a single member.

All the evidences that have been described above inevitably leads to the conclusion that indeed there was asymmetric information between cooperative authority of Keerom Regency with the cooperatives under is coordination. This asymmetric information would then lead to agency problema or principal-agent problema, namely adverse selection (selection error/wrong choice). As presented by Miller (2003), the emergence of adverse selection was due to the inability of principal (local cooperative authority) to examine the characteristics 
and properties of its agents (the cooperative including the managers) and every possibility that surrounds them, such as: whether a cooperative is active or not, whether it has members or not, and many others, hence the cooperative empowerment programs in Keerom Regency could be received by the wrong cooperatives, or the inactive ones, or the ones that are ineligible to participate in the program (the evidences on the occurence of adverse selection have been described within Section 3). Cooperative authority of Keerom Regency was unable to recognise which cooperatives are eligible to be granted funding assistance, due to the asymmetric information condition.

In addition to adverse selection, agency problem due to asymmetric information also leads to the emergence of moral hazard problems (moral deviation). Moral hazard is the tendency of unresponsible behaviour in maintaining good morale, which occurs intentionally and recognised by the cooperative management (agent) that is executed secretly so would not knwon by the cooperative authority (as the principal). In other words, due to the asymmetric information, cooperative managements can take action for their own sakes, and not in the interest of the cooperative authority. Cooperatives will forget the interests or the policies set by the cooperative authority. This is supported by the fact that the cooperative is in a position of obtaining a more complete information compared to the cooperative authority, leading to the cooperatives having a lot of ooportunities to take action for its own shake. In this case, moral hazard in terms of opportunistic behaviour such as: manipulation, deception, and neglection of duty, which would definitely lead to the increase of the transaction fee that has to be borne by the transactors, such as: the Government or the cooperative authority, as well as the community.

\section{b. Conflicting Objectives}

In this case, agency problem could also arise due to the differences in interests or objectives (conflicting objectives) between the cooperative authority (principal) and the cooperative (agent). If there is no conflicting objectives between the principal and the agent, and they have symmetric information, then ther will be no agency problem within their relationship. What is the real form of the conflicting objectives? Cooperative authority would certainly put forward the intresets of the majority, which is the community as the ultimate target for the empowerment. In contrast to cooperatives management, as the enterpreneur, would certainly emphasize on the optimization of the business opportunities (the profits of the business) to the interests of the managemen team and the members. However, in this case, the cooperative management was not managing to the interest of the members, but to their own interests, which is the kind of interests that were not appeared on the surface (hidden agenda). It would then lead to moral hazard that were manifested throug opportunistic behaviours, which also resulted in the increasingly high transaction fee that has to be borne by the transactors.

In the case of P3KUM program for example, an objective or the interest of the program is implemented bt the Cooperative Authority to bring forth an increase and a development in the economically productivity of the society. As for a number of cooperative management teams, these kind of programs is seen as an opportunity (as referred to as opportunistic behaviour) in orde to realize their personal interests (hidden agenda). One of the forms of hidden agenda that can be found in the fiels is that revolving funding assistance was used top ay for the college fee of one of the board member of the cooperative. This is a form of opportunistic behaviour that was done by one of the board member of a cooperative which is also a manifestation of his moral hazard due to the asymmetric information between the Cooperative Authority of Keerom Regency with the cooperatives under its coordination.

\section{c. $\underline{\text { Rent-Seeking }}$}

Rent-seeking is the act of the politicians, elites, and other influential groups seeking economic gain without going through the correct procedure (Acemoglu, 2003 in Yustika, 2006). Rent-seeking can also be a form of behaviour (rent-seeking behaviour) in order to gain an advantage by utilizing the power of the Government. Asymmetric information is a driving factor behind the emergence of rent-seeking behaviour. Those who are within the Government office would understand the inability of the principal (Cooperative Authority) to examine the characteristics and properties of its agents (the cooperative itself and the management team) and all the possibilities surrounding them due to the asymmetric information.

Apart from the above direction, asymmetric information can also occur from the bottom. Information concerning the existence of cooperative empowerment program cannot be obtained directly form the management team of a cooperative (agent). The cooperative management team did not even know when the program would start, what the requirements to be able to partake in the program are, and the source of the funds. By utilising the influential power within the Government, Cooperative Authority member seeks to benefit from this situation. They would make a condition for certain cooperatives to be their "vehicle" to gain access to the empowerment programs from the local Government. 


\section{d. Social Capital}

As with mosy of the regions in the Province of Papua, the social condition of the Keerom Regency is laso characterised by the low capacity of social capital. Inter-tribal conflicts still occur, to the point where there would be casualites. Additionally, the dichotomy between the Keerom natives and the immigrants can strongy be sensed. Harmony, solidarity, or trust can be well sensed, but that only applies within the community of one tribe. When the focus is expanded to many tribes, or between the natives and the immigrants, then it would appear otherwise.

Associated with the cooperative empowerment programs in Keerom Regency, the low capacity of social capital has become one of the obstacles or even the cause of not achieving some objectives of the program. Why is that? Normatively, cooperatives should mean cooperation. When the elements of social capital that can encourage the presence of cooperation, sch as harmony, trust, or solidarity are not visible, then the existence of the cooperative would be over. One of the cause of the inactiveness of Cooperative One was due to the lack of harmony, trust or even solidarity between the many coexisting tribes. The members who are from different tribe to the management team has less sense of ownership of the cooperative. They are only taking advantage of the existence of the cooperative. Only those who are from the same tribe as the management team that would have a sense of owneership of the cooperative. However, due to the small number of such members, the cooperative was inevitably ended. Moreover, the cooperative was not able to sell the wares to the public due to the same factor, which is tribalism.

Due to the low capapcity of social capital in Keerom Regency, the community is still fragmented with a very low degree of social cohesion. It is also an obstacle to successful implementation of the cooperative empowerment programs in Keerom Regency. Bastelaer (2000) also shared the same opinion that one of the major determinants of successful credit program (aid) in many developing countries is social capital. In other words, success or failure of funding assistance program depends on how the capacity of social capital in the object environment is.

\subsection{Environment Aspect \\ a. Economic Condition}

The production of plantation crops in Keerom Regency is still dominated by oil palm plantations. Harvested area of the oil palm stretched out to be as wide as 14,244 hectare with total production up to 183,920 tonnes, where its cotribution to PDRB - Pendapatan Domestik Regional Bruto (Gross Domestic Product) in 2009 , amounted to $11.34 \%$. Unsurprisingly most of the members of cooperatives in Keerom Regency work in the plantation sector, especially oil palm plantations. There are land owners or managers, there are also the workers (laborers) of the plantation. When there is a change in the counterproductive of the variables that affect the revenue of the owner, or land managers, or the laborers of the oil pam plantations, such as a decline in demands, decline in prices, increase in production costs, or even an increase in transportation expenditure, will inevitably affect their ability to pay their installment loans from the cooperatives, if they are members of a cooperative. The efffect would be on the performance of the cooperative empowerment program due to the low cooperative repayment rate.

When ther is a decline in selling prices of oil palm from Rp1.500 to Rp 500 per kilogram, then their income would automatically drop to only Rp 600 thousand a month. Whereas the production cost would not decline, instead it would rise, comparably the transportation expenditure would rise from $\mathrm{Rp} 200$ thousand to $\mathrm{Rp}$ 300 thousand per truck. Total production cost plus transportation fee to be incurred monthly rise up to Rp 590 thousand. As a result, the net profit for the farmers is only Rp 10 thousand per month. With such income, how can the farmers, who are also members of the cooperatives, repay their loans? This, in turn affects the breakdown of numerous loans in cooperatives, and the ultimate effect would be the ineffectiveness of several cooperative empowerment program in Keerom Regency.

\section{b. Infrastructure}

The condition of the infrastucture in Keerom Regency, especially transportation and communications, is still considered to be inadequate for the implementation of cooperative empowerment programs. There are no mass transportation facilities that can sufficiently facilitate the community in Keerom Regency. Public transportation is limited and serves only one way, which is from Arso District to Abepura public transport terminal in Jayapura. The most type of public transportation are motorcycle taxis and rental cars. There are many road that connects the regions in Keerom Regency that are not paved, and some of them are even barely usable dirt road for the vehicles, especially when it rains. This condition that inhibit access to and from the location of each cooperatives is causing a decrease in the amount of visits and assistance that should be done by the Cooperative Authority of Keerom Regency. This is one of the causes of asymmetric information between the cooperative Authority of Keerom Regency and the cooperatives. 
Regarding the infrastructure of the communications, there is not much of a difference to the transportation condition. Wired telephone network do not exist in Keerom Regency. While the mobile phone networks reach only the district that are located cloe to the centre of the Regency, but it is still very weak. Suppose that there is adequate telecommunication system, it woul dbe used to suppress the asymmetric information condition that occurs through the creation of cooperative electronic reporting system.

\section{c. Social and Cultural Rights}

The way of thinking of most people that any funds received from the Government are the mone yo be divided among them, funds that they deem as their right, therefore do not need to be returned. Likewise, when they realise that the funds they are borrowing are sourced from the Government. This kind of behaviour is what causing a lot of loans in the cooperatives become insolvent.

In the case of Cooperative Three, revolving funds assistance that was channelled to the cooperatives, which is then disbursed by the cooperative to its members, by a majority of the members was considered as grants that should not be returned. Although this misperception had been thoroughly clarified by the board members, but they still insisted on their opinion. Similar thing occured in many other cooperatives. Moreover, this kind of incident did not only happen in the form of cash loans, but also occured when the loans were in the form of goods. This way of thinking and behaving have been entrenched in most societies due to the many grant programs that were given away without any obligation to be returned. The grant programs, among others, were: Respek - Rencana strategi pembangunan kampung (the village development strategy plan), B3K - Bantuan keuangan kepada kampung (Financial assistance to the vilage), and others. Respek is a program that was initiated by the Provincial Government of Papua in the form of distribution of grant funds to villages across the province of Papua, where each village would receive Rp 100 million. For villages in remote areas, they would get more than $\mathrm{Rp} 100$ milion, could reach up to a maximum of Rp 250 million. Whereas $B K 3$ is a product of the local management of Keerom Regency, which also appeared as a distribution of grant funds to villages throughout the Keerom Regency, where each village would receive Rp 1 billion. Since the society is used to such commodities, hence when there is an empowerment program, even loans from cooperatives, were considered as a commodity that need not to be returned.

In addition, bounded rationality of the Cooperative Authority of Keerom Regency as the organizer and implementer of the program was found, which caused some constraints to input every complex concepts associated with the cooperative empowerment program in the planning stages, thus, as a result, the empowerment programs was unsatisfactory when it was in the level of implementation. Bounded Rationality also occured to the cooperative management team and its members. Many cooperative management teams do not fully understand the concepts of cooperatives and cooperative management. As a result, there are many cooperatives that have bad credit due to mismanagement. There are countless poeple who just went along and became members of a cooperative, without fully understanding the concept of coopeative, which then resulted in misinterpreting the loans as one of the grant funds given by the government.

Williamson (1995) stated that bounded rationality would also have impacts $\mathrm{n}$ the rising cost of the transaction. The limited ability of the Cooperative Authority in planning for empowerment program, the low ability of administrators in managing the cooperative, as well as the low level of understanding of the public as the memebrs of the cooperative, would eventually lead to the failure of implementation of the program, and when the empowerment programs fail to achieve their objectives, which are caused by a number of things described above, maladaptation of positive transaction cost would occur.

\section{What Is The Best Way Of Empowering The Cooperatives In Keerom Regency?}

In order to achieve successful implementation of cooperative empowerment programs in Keerom Regency, the constraints described previously should, surely, be overcome, or at least reduced in advance, and the government would play a huge role in it, especially the Regime of Keerom Regency.

In reducing asymmetric information condition, one of which, the Cooperative Authority can take advantage of the advancement of information technology. Monthly cooperative reports, quarterly, as well as anually, can be accessed in real ime. Transparant selection of the cooperatives that deserve to be aided, must also occur, therefore the Cooperative Authority can form a partnership with LSM - Lembaga Swadaya Masyarakat (non-governmental organizations) or even universities to materialize it. In addition, improvement of the infrastructure condition, both transport and telecommunications, can indirectly be able to reduce the asymmetric information situation. If the symmetric information situation has been realized, expectedly it would cause the reduction of problems like conflicting objectives and rent-seeking.

Regarding economic constraints associated with the unstable oil palm prices, the Government needs to conquer it by implementing policies that can encourage the improvement of the qualiy of oil palm production, since the decline in oil palm value is due to the low quality production of the oil palm itself. Policies that can be 
implements are, for example: shortening the economic life of the oil palm from 25 years to 15 years. The Golden time of oil palm production is, in fact, from when it is 1 year old to 15 years old, but over the years, oil palm continues to be forced to produce up to 25 years old. Due to the shortening of the economic life, the expansion of land is abbsolutely necessary, especially if it the cropping system is by the age of the tree, so that the production can continue to be sustained. Another measures that can be applied in regards to the improvement of the quality of oil palm production is to multiply the research activities to obtain high yielding varieties of oil palm seedlings.

Education or training seems to be another effective way that can be applied by the government to reduce the existence of bounded rationality, whether within the Cooperative Authority, cooperative management team, or even the members. Reinforcing the concepts of cooperative into the formal education curriculum is also another alernative. Another alternative that is more effective is, the establishment of social gathering groups should be advised prior to the establishment of the cooperatives. Within the social gathering group, the society is, indirectly, trained to work together, which is one of the main foundation of cooperatives so that after the cooperative is establihed, the members would be able to work in harmony with each other and implementing the principle of mutual help cooperative. In Arso District, close to the location of Cooperative Two, there is a social gathering group. There are also the saving and loan activities. Therefore, through such social gathering group, they can be trained to overcome daily needs problems together since there is also a social gathering gropu dedicated solely for basic needs trading. They are learning to be more independent through such social gathering group, and they are planning to establish a cooperative out of their social gathering group.

The establishment of a social gthering group can also be exploited to overcome the obstacles related to the assumptions of the public that every financial assistance from the government is to be divided among the community and need not to be returned because it is considered as the rights of the people.Savings and loans activities within the group will slowly erode that kind of thinking, especially if there are special training supplemented. To carry out such training, the government can, again, form partnership with the nongovernmental organisations ore ven universities.

Another benefit from the establishment of the social gathering group is that it can increase the capacity of community social capital. It can be seen that in a sociaering group, the members are not only by the settlers, the local natives are also starting to be intereseted in joining. This proves that this kind of groups can encourage the presence of harmony, solidarity, or trust, and these three are the elements that can encourage the presence of cooperation which is the purpose of a cooperative. The accumulation of social capital can be even more effective if the government would involve the church. Internalization of religion and society norms, as well as the value of harmony, solidarity, or trust, will be more effective if it is included within religious sermons in churches.

If every constraint can be reduced by a number of methods decribed above, then the implementation of cooperative empowerment programs in Keerom Regency can effectively achive its objectives, which is the development of the community (cooperative members), becasue, surely, there is nothing wrong with programs such as: P3KUM, Perkassa, and others, the upreparedness of the object, subject, and the the environment of the implementation of the programs are the real issues. However, a number of supporting conditions must be fully implemented in order to achieve the program objecives. First, empowerment with the concept of grants must be abandoned, implementation of the non-grant concept or revolving funds model, since this model can encourage the cooperative abd the community (the members) to be more independent, profesional and competitive. Second, it is necessary to install the concept reward and punishment into the implementation of cooperative empowerment programs. Reward can be given, for example, in the form of interest rate cut for the cooperatives, who are able to return the entire outstanding funds before or on the maturity date of the program. Whereas punishment, especially for the 'naughty' cooperatives management teams, should really be carried out in accordance with the applicable law. Third, in any implementation of cooperative empowerment program, it should always be followed by activities such as: mentoring, coaching, and control. Cooperative Authority can involve independent parties such as churches, non-governmental organisation, and universities.

\section{Conclusion}

The beauty of the coopeartive empowerment program while still at the level of planning or concept is not as nice when it is on the level of implementation. Many objectives of empowerment programs are not realised since there are many cooperative, which obviously do not qualify, can still gain partake in the program, there are some with no members at all, and can still get involved in the program. It was also found that there are violations of the macimum limit of the revolving funds assistance to cooperatives, as well as violations of use of revolving funds assistance.

The constraints that cause the unsuccessfulness of the cooperative empowerment in Keerom Regency consist of two aspects, they are institutional and environmental. Institutional aspect consists of: asymmetric information, conflicting ojectives, rent-seeking behaviour, and the lpw caacity of social capital. Whereas the environmental aspect consists of: economic condition due to the decline of oil palm prices, inadequate transpor 
and communication infrastructure, as well as bounded rationality and the culture of the people, which suggests that every financial assistance that comes from the Government is grant fund.

The strategy for the implementation of cooperative empowerment program in the Keerom Regency so that it can achieve its objective is to overcome or reduce in advance all the constraints or obstacles encountered. In its implementation, the grant funds concept should be abandoned since it is causing dependent behaviour, unprofessionalism, as well as a loss of competitiveness of cooperatives. The reward and punishment concept also needs to be implemented into the empowerment program. In addition, it is neccessary to involve the church, nongovernmental organisations, and universities in terms of coaching, mentoring and controlling.

\section{References}

[1]. Dinas Koperasi, UKM, Perindustrian dan Perdagangan Kabupaten Keerom. 2011. Keragaan Koperasi di Kabupaten Keerom Tahun 2011. Dinas Koperasi, UKM, Perindustrian dan Perdagangan Kabupaten Keerom.

[2]. Miller, Nolan. 2005. Notes on the Principle-Agent Problem. http://www.people. fas.harvard.edu/ aeggers/patheory.pdf

[3]. Mishkin, Frederic S. 1997. The Economics of Money, Banking, and Financial Markets. Fifth Edition. Addison-Wesley, USA.

[4]. Nicholson, Walter. 1995. Microeconomic Theory: Basic Principles and Extentions. Sixth Edition. Harcourt Brace College Publishers dan The Dryden Press, USA.

[5]. Republik Indonesia. 1992. Undang-undang Republik Indonesia Nomor 25 Tahun 1992 Tentang Perkoperasian. Pasal 26.

[6]. Sumodiningrat, Gunawan. 1999. Butir-butir pemikiran strategi menghapus kemiskinan dalam pembangunan pedesaan. Dalam Pembangunan Ekonomi Rakyat di Pedesaan Sebagai Strategi Penanggulangan Kemiskinan (Penyunting Hasan Basri), Cetakan Pertama, hal 140-154. Bina Rena Pariwara, Jakarta.

[7]. Van Bastelaer, T. 2000. Does Social Capital Fasilitate The poor's Access to Credit? A Review of Microeconomic Literature. Social Capital Inisiative Working Paper No. 8, World Bank.

[8]. Varian, Hal R. 1993. Intermediate Microeconomics: A Modern Approach. Third Edition. W.W. Norton \& Company, New York dan London.

[9]. Williamson, Oliver E. 1996. The Mechanisms of Governance. Oxford University Press, New York.

[10]. Yustika, Ahmad Erani. 2006. Ekonomi Kelembagaan; Definisi, Teori dan Strategi. Penerbit Bayumedia, Malang. 